6th International Conference on Industrial Engineering and Industrial Management.

XVI Congreso de Ingeniería de Organización. Vigo, July 18-20, 2012

\title{
Operational characterisation of a Micro-SME producing farmhouse cheese in the south of Venezuela.
}

\author{
Rodríguez Monroy C 1, Cardozo E, Guaita W, Pelaez M.
}

\begin{abstract}
A piece of research is presented that was conducted on the Guayanes Farmhouse Telita Cheese Producers Network located in the Piar and Padre Chien rural municipalities of Bolivar state in Venezuela. Guayanes telita cheese is a regional dairy product. The producers are to be found in a rural area with a high potential for marketing the label in the Southern Common Market (MERCOSUR). This market is the focal point of the strategic importance of this study for the Region and the Country. The research is of a descriptive scope conducted in the field. A questionnaire based on good food production practice was used as a data gathering technique. The final sample comprised 30 production units. Statistical processing was performed with version 15.2 of the STATGRAPHICS Centurion computational tool. The results would appear to confirm previous studies that point to the existence of factors that prevent these Micro-SMEs from guaranteeing the food safety of the product. The results indicate that new lines of research need to be opened up. These are oriented towards formulating strategies for the continuous improvement of these micro-SMEs, including quality control indicators.
\end{abstract}

Keywords: Operational characterisation, Micro-SMEs, farmhouse cheese, dairy industry

\section{Introduction}

Venezuelan cheeses like many Latin American cheeses have their origin in Europe. Regional and provincial peculiarities have led to their being labelled as different. Their production, though on a smaller scale, has much in common with that

${ }^{1}$ Carlos Rodríguez Monroy ( $\left.\square\right)$

Departamento de Ingenieria de Organización Administración de Empresas y Estadística. Escuela Técnica Superior de Ingeniers Industriales. Universidad Politécnica de Madrid. Calle José Guatierrez Abascal \# 2, Madrid 28006. España. e-mail: crmonroy@etsii.upm.es 
of countries with a cheese-making tradition both in Latin America as well as in the United States and some European countries. The production systems to be found in these Micro-SMEs are basically family-run businesses with a low level of technological and organisational development. They extend to regional contexts and may be considered as farmhouse production (Aragón and Marin, 2003; López and Castrillón, 2007; Espinosa, 2009). In many cases, the producers concentrate on exotic products that have a short shelf-life and are intended for a restricted regional market, which is the case being researched in this paper.

Cheese according to the FAO, can be classified according to the percentage of fatfree moisture it contains. It can be denominated as extra-hard, hard, semi-hard, semi-soft or soft. Soft pasta filata cheese is a category recognised by the Codex Alimentarius (FAO, 1978). Mozzarella cheese is placed inside this category. Also placed in this category is Guayanes telita cheese, which is a soft unmatured cheese that is ready for consumption soon after production.

Guayanes telita cheese is mainly made in the traditional way and owes its name to the region of Guayana where it originates. It is characterised by its soft flavour, creamy appearance, low salt content, having medium fat and its soft texture (Márquez and García, 2007). Because of its popularity its production has become extended to different parts of the country. Bolivar State is still the leader with production being concentrated in the rural municipalities of Piar and Padre Chien. Both municipalities belong to the south-east livestock corridor of Venezuela and are acknowledged for their livestock tradition.

The small enterprises producing this exquisite regional product have grouped together in the Guayanes Farmhouse Telita Cheese Producers Network. As a whole they process over 30,000 litres of raw milk every day and produce almost 6,000 kilos of cheese. They have an employment capacity of over 600 direct and indirect jobs.

The medium term goal of this Network is to obtain a Quality Certification and, in the future, the indication of origin label for the entire product cycle. This is a challenge that will force the enterprises to implement a strategy of improvement and self-regulation in their processes. In addition, Venezuela's future membership of the Southern Common Market (MERCOSUR) will also bring challenges that can only be taken up from a standpoint of competitiveness and quality.

Research so far has focused on the product. In this respect, various studies have been made to determine the level of food safety of Guayanes telita cheese. Although most studies have concentrated on the physical-chemical and organoleptic qualities of the product (Márquez and García, 2007; Colina and Xiquez, 2007; Rodríguez et al., 2009), researchers have observed weak points in the internal systems.

\section{Methodology aspects}

The purpose of this research was to undertake an operational characterisation of the small production units joined together in the Guayanes Farmhouse Telita 
Cheese Producers Network. The population is made up of 45 units and at the time of this study 38 were active. Of these, 8 contributed no information. Therefore, the final sample consisted of 30 production units that represent $66.67 \%$ of the population, which can be regarded as a significant sample.

A questionnaire based on good food production practice was used as a data gathering technique. The questionnaire included: employment capacity, raw material handling, environmental conditions of the production process, sanitary aspects, work area, workers' personal protection system, laboratory analysis and production capacity in kilos. Version 15.2 of STATGRAPHICS computational software was used for data processing.

\section{Results}

These micro-SMEs possess the features of a family-run business (Acosta and Rodríguez, 2006). Due to their size, their production process is basically horizontal. Their value chain comprises three major stages: raw material supply, collection and processing, which, in turn, comprises the operations of curdling, designing the mixture and the end product (cooking-moulding-packaging). For the purposes of this study each stage of this value chain was characterised.

By taking the results of the questionnaires, from a micro-SME size-related theoretical perspective, four layers were found for classification purposes. They are based on production capacity as a relevant criterion; that is, the volume of milk processed and the production in kilos. When the variable regarding the number of workers was analysed, two criteria that were in keeping with the classification provided by the authors attempting to define an SME were chosen during the layering process (González, 2005; Saavedra and Hernández, 2008; Aragón-Correa, Hurtado-Torresa, Sharmac and García-Morales (2008); Herbane, 2010; Hillary, 2000). Table 1, shows how the enterprises were classified.

Table 1. Enterprise classification

\begin{tabular}{ccccc}
\hline TYPE & WORKERS & $\begin{array}{c}\text { PROCESSED } \\
\text { MILK } \\
\text { (litres per day) }\end{array}$ & $\begin{array}{c}\text { QUANITY OF } \\
\text { PRODUCT (kilos) }\end{array}$ & $\begin{array}{c}\text { \% OF } \\
\text { ENTERPRISES } \\
\text { (Two criteria) }\end{array}$ \\
\hline IV & Up to 3 & Up to 1500 & Up to 200 & 73.3 \\
III & 4 to 6 & $\begin{array}{c}\text { Between } 1501 \\
\text { and } 3000\end{array}$ & 201 to 400 & 20.0 \\
II & 7 to 9 & 3001 to 4500 & 400 to 600 & 6.7 \\
I & 10 to 13 & 4501 to 6000 & 600 to 800 & 0 \\
\hline
\end{tabular}

The small enterprises studied receive between 160 and 3,700 litres of milk per day for processing. The highest daily production of cheese recorded is 740 kilos and 
the lowest, $38 \mathrm{Kg}$. The unit employing the most staff amounts to 9 people per enterprise, while the least amounts to only one worker.

As to the layers identified: $73.3 \%$ of the enterprises are to be found in layer 4, which is the smallest layer, while $20 \%$ are in layer 3 , and $6.7 \%$ in layer 2 , the largest layer. No production units were found to be in layer 1 . However, if the amount of product produced is taken as a classification criterion, then one of the enterprises can be positioned in this layer.

From what is stated above, it can be said that, taken one by one, they fit in the context of micro-enterprises or micro-SMEs.

To analyse the operational characteristics every stage and its categories were analysed. Each category was broken down into variables to facilitate data processing (see Table 2).

Table 2. Category and Variables

\begin{tabular}{|c|c|c|c|c|c|c|c|}
\hline STAGE & $\begin{array}{c}\text { Raw } \\
\text { material }\end{array}$ & Collection & \multicolumn{5}{|c|}{ Production process } \\
\hline CATEGORIES & $\begin{array}{c}\text { Raw } \\
\text { material } \\
\text { handling }\end{array}$ & $\begin{array}{c}\text { Raw } \\
\text { material } \\
\text { preparation }\end{array}$ & $\begin{array}{c}\text { Environmental } \\
\text { conditions } \\
\text { (production } \\
\text { process) }\end{array}$ & $\begin{array}{c}\text { Sanitary } \\
\text { aspects }\end{array}$ & Work area & $\begin{array}{c}\text { Personnel } \\
\text { protection } \\
\text { system }\end{array}$ & $\begin{array}{c}\text { Laboratory } \\
\text { analysis }\end{array}$ \\
\hline \multirow[t]{6}{*}{ VARIABLES } & $\begin{array}{l}\text { Reception } \\
\text { temperature }\end{array}$ & $\begin{array}{l}\text { Milk } \\
\text { filtering }\end{array}$ & Gas & Mains water & Work table & Gloves & Temperature \\
\hline & $\begin{array}{l}\text { Container } \\
\text { type }\end{array}$ & $\begin{array}{l}\text { Milk } \\
\text { collection } \\
\text { container }\end{array}$ & $\begin{array}{l}\text { Refrigeration } \\
\text { System }\end{array}$ & $\begin{array}{l}\text { Drainage } \\
\text { systems }\end{array}$ & Moulds & Cap & Acidity \\
\hline & & & & $\begin{array}{l}\text { Sanitary } \\
\text { licence }\end{array}$ & Vat/tub & Clothes & Density \\
\hline & & & & $\begin{array}{c}\text { Waste } \\
\text { handling }\end{array}$ & Floors & Boots & Pasta texture \\
\hline & & & & & Walls & Mouth mask & $\begin{array}{l}\text { Rennet } \\
\text { type }\end{array}$ \\
\hline & & & & & Windows & $\begin{array}{l}\text { Health } \\
\text { certificate }\end{array}$ & \\
\hline
\end{tabular}

Since the data were categorical data, they were encoded for processing. The variables were tabulated one by one using the STATGRAPHICS version 15.2 statistical software package.

During the raw material supply stage (reception of raw milk from the different supply farms), it was observed that $100 \%$ of the enterprises measured the temperature, an aspect that can be considered as standardised. Regarding the type of container for milk reception, $83 \%$ use polyethylene containers. These containers are usually recycled ones coming from other production systems which have been recovered for this specific use. Once the milk goes on to the collection stage, the containers are again recovered to be used in subsequent processes.

The collection stage is vital. The milk received is mixed together and made ready for cheese production. This stage must include filtering, temperature standardisation and its pouring into the containers where the mixture is prepared. According 
to the data obtained, $76.7 \%$ of enterprises filter the milk, while $23.3 \%$ did not respond, which would suggest that they do not do so. As for the container used to collect the milk after filtering, $56.7 \%$ use stainless steel containers, $20 \%$ use polyethylene containers and $16.7 \%$ use wooden ones, while $6.7 \%$ provided no information.

The production process stage is the stage where the cheese is actually produced. It is the most complex stage where the following categories were analysed for this study: environmental conditions of the production process, sanitary aspects, work area, personnel protection system and laboratory analyses.

Under normal environmental conditions $80 \%$ use gas canisters for cooking while $20 \%$ provided no information.

$43.3 \%$ possess a refrigeration system while $43.3 \%$ do not and $13.3 \%$ provided no information.

As for the sanitary aspects category, 70\% have no mains water supply, $43.3 \%$ use the public drains network, $23.3 \%$ throw the waste into the open without any processing, and $30 \%$ provided no information. While $26.7 \%$ have a health licence the rest do not or provided no information and only $26.7 \%$ process the waste.

In the work area category, it was observed that $76.7 \%$ use cement or ceramic work tables and $20 \%$ stainless steel tables, while $3.3 \%$ provided no information. Regarding the use of moulds, the most significant was: $23.3 \%$ use silicone rubber moulds, $16.7 \%$ stainless steel ones, $16.67 \%$ wooden ones and $23.3 \%$ combine different types of material in their moulds. Regarding the vat or tub used for mixing, $63.3 \%$ possess a stainless steel vat or tub, $16.7 \%$ a ceramic one and $10 \%$ were made of polythene, while the rest provided no information. In respect of the flooring in the work area, $53.3 \%$ had it covered, of which $43.3 \%$ was granite or cement, while the rest provided no information. $73.3 \%$ of walls were covered while $6.7 \%$ were bare and $20 \%$ provided no information. Regarding windows, $40 \%$ had none while $50 \%$ provided no information but the rest had windows.

The personnel protection system category produced the following results: $56 \%$, provide gloves for staff, $43.3 \%$ provide caps, $43.3 \%$, provide working clothes, $40 \%$ provide safety shoes and $70 \%$ provide mouth masks while $63.3 \%$ do not request staff to have any Health Certificate.

In the Laboratory Analysis category that was performed during the first and last stage, it was found that $16.7 \%$ took no temperature measurements during the production process, $56.7 \%$ analysed the acidity of the mixture, $63.3 \%$ made density checks and $83.3 \%$ checked the type of rennet.

\section{Conclutions}

The results found agree with the studies made that confirm the inability of these small production units to guarantee the food safety of the product (Márquez and García, 2007; Rodríguez et al., 2009). 
The enterprises reveal operational situations that require improvements. The conditions necessary to meet the requirements of quality certification for the product and obtain the indication of product label need to undergo adaptation processes.

This study is an attempt to learn more about the micro-SMEs that are grouped together in the Guayanes Farmhouse Telita Cheese Producers Network. It provides relevant information that can be used to plan future improvement strategies that will lead to their becoming more competitive. If the product is to achieve certification and a future indication of origin label, it will have to meet international quality standards for the entire cheese-making cycle. In this respect, this study can be a starting point for achieving these goals.

We need to consider implementing a continuous improvement model based on the principles of lean production that will be measured by control systems at every stage of production. It must include all the inspection-correction-handling stages, as well as productivity indicators.

The analytical process and the procedural basis used can be applied to similar small enterprises.

The new lines of research are directed towards an analysis of the regional production system, with emphasis on the dairy sector to establish the levels of differentiation of the micro dairy enterprises in rural municipalities and how this impacts on their development.

\subsection{Referencias}

Acosta LA, Rodríguez MS (2006) En busca de la agricultura familiar en América Latina. Oficina Regional de la FAO para América Latina y el Caribe, Disponible en: http://www.rlc.fao.org/prior/desrural/busca.htm

Aragón SA, Marín SG (2003) Orientación estratégica, características de gestión y resultados: un estudio en las PYME españolas. Tribunal de Economía, publicación de Información comercial española, Ministerio de Economía. 809:169-187.

Aragón-Correa JA, Hurtado-Torresa N, Sharmac S et al. (2008) Environmental strategy and performance in small firms: A resource-based perspective. Journal of Environmental Management. 86(1):88-103

Colina P, Xiquez A (2007) La producción artesanal de queso guayanés en los municipios Piar y Padre Chien, estado Bolivar. Revista Autana. Departamento Hombre y Ambiente. Universidad Nacional Experimental de Guayana. Ciudad Guayana. Volumen 1: 54-60

Espinosa AE (2009) La competitividad del sistema agroalimentario localizado productor de quesos tradicionales. Tesis doctoral de la Universidad Autónoma del Estado de México. Disponible en: http://www.eumed.net/tesis/2010/eea/index.htm

FAO-CODEX (1978) CODEX STAN 283. Norma general del CODEX para el queso. Organización de las naciones unidas para la agricultura y la alimentación. Codex Alimentarius. Disponible en: www.codexalimentarius.net/download/standards/175/CXS 283s.pdf

González AT (2005) Problemas de la definición de la microempresa. Revista Venezolana de Gerencia. 10(31):408-423

Herbane B (2010) Small business research: Time for a crisis-based view. International Small Business Journal. 28(1):43-64. 
Hillary R (2000) Small and medium-sized enterprises and the environment: business imperatives. Greenleaf publishing limited. Shefiel, UK

López MF , Castrillón P (2007) Teoría económica y algunas experiencias latinoamericanas relativas a la agroindustria. Libros EUMED. Disponible en: www.eumed.net/libros/b2007/304

Marquez JG, Garcia RCE (2007) Efecto de la nisina sobre la microflora patógena del queso blanco artesanal tipo"telita" elaborado en una quesera de Upata, Estado Bolívar, Venezuela. Revista de la Sociedad Venezolana de Microbiología. 27:108-111

Rodríguez C et al. (2009) Calidad sanitaria en queso artesanal tipo "telita". Upata, Estado Bolívar, Venezuela. Revista de la Sociedad Venezolana de Microbiología. 29(2): 98-102

Saavedra GML, Hernández CY (2008) Caracterización e importancia de las MIPYMES en Latinoamérica. Un estudio comparativo. Actualidad Contable FACES. 11(17):122-134. 